\title{
INORGANIC SULPHATES IN HUMAN BLOOD
}

\author{
By ROBERT F. LOEB AND ETHEL M. BENEDICT \\ (From the Department of Medicine, College of Physicians and Surgeons, Columbia Uni- \\ versity, and the Presbyterian Hospital)
}

(Received for publication October 7, 1926)

\section{INTRODUCTION}

In recent years, many of the electrolytes of the blood have been intensively studied under normal and pathological conditions in human beings. The inorganic sulphate ion has not participated in this general interest, as has been pointed out by Denis (1), because of the minute amounts normally present and because of its apparent lack of importance from a physiological standpoint.

Denis, in 1921, reported a large number of $\mathrm{SO}_{4}$ determinations, made nephelometrically, on human blood in normal individuals and in various diseases. In view of the fact that this is the only comprehensive study of this subject in addition to those of White (2) and Kahn (3), it seems justifiable to report a similar series of observations made some years ago by a gravimetric method even though the results merely confirm those of Denis.

\section{METHOD}

One drop of caprylic alcohol and $10 \mathrm{cc}$. of serum are placed in a $50 \mathrm{cc}$. volumetric flask. To this are added $10 \mathrm{cc}$. of water and $30 \mathrm{cc}$. of saturated aqueous picric acid solution. After thorough mixing, the contents are rapidly centrifuged (to avoid evaporation) and the supernatant fluid is filtered. A $30 \mathrm{cc}$. aliquot is placed in a $50 \mathrm{cc}$. beaker and $5 \mathrm{cc}$. of one per cent $\mathrm{BaCl}_{2}$ solution are slowly added. The precipitation is allowed to go on for at least 6 hours and then the solution is filtered through a $7 \mathrm{~cm}$. ash free filter paper (sometimes two to four filtrations are necessary) and the precipitate is washed 5 times with $4 \mathrm{cc}$. of water acidulated with $\mathrm{HCl}$. The filter is ignited slowly in a weighed platinum crucible with the lid only slightly open until charring has occurred. Later, the lid is kept about half open to prevent excessive reduction of $\mathrm{BaSO}_{4}$. Care must be taken not to allow the filter to burst into flame. Ignition should take about 25 minutes. The crucible should be weighed as soon as it is cool. A certain amount of reduction of 
TABLE 1

Addition and recovery of $\mathrm{SO}_{4}$ from serum

\begin{tabular}{c|c|c|c}
\hline \multirow{2}{*}{ SO 4 added } & SO4 recovered & \multicolumn{2}{|c}{ Calculated as SO per 100 cc. serum } \\
\cline { 2 - 3 } & & Found & Theoretical \\
\hline$m g m$. & $m g m$. & $m g m$. per 100 cc. & mgm. per 100 cc. \\
2.00 & 1.92 & 26.0 & 26.8 \\
2.00 & 1.85 & 21.2 & 22.7 \\
2.00 & 1.89 & $24.7^{*}$ & 25.8 \\
2.00 & 1.89 & $25.6^{*}$ & 25.8 \\
2.00 & 2.05 & $27.4 \dagger$ & 26.9 \\
2.00 & 2.19 & $28.8 \dagger$ & 26.9 \\
1.00 & 0.89 & 15.1 & 16.1 \\
1.00 & 1.30 & 17.8 & 14.8 \\
\hline
\end{tabular}

N.B.: Determinations marked $(*)$ and $(\dagger)$ are duplicates.

TABLE 2

Normals

\begin{tabular}{|c|c|c|c|c|c|}
\hline \multirow[t]{2}{*}{ Number } & \multirow{2}{*}{$\frac{\mathrm{BaSO}_{4} \text { weighed }}{m g m .}$} & \multicolumn{2}{|c|}{ Expressed as $\mathrm{SO}_{4}$ in serum } & \multirow{4}{*}{$\begin{array}{c}\text { Urea } \mathrm{N} \\
m g m . \text { per } 100 c c . \\
13.3 \\
12.2\end{array}$} & \multirow{2}{*}{$\frac{\text { Non-protein.N }}{m g m . \text { per } 100 c c .}$} \\
\hline & & $m g m$. per $100 \mathrm{cc}$. & $m E q . \operatorname{per} L$ & & \\
\hline Lo & 0.4 & 2.7 & 0.6 & & 28.3 \\
\hline Lo & 0.5 & 3.4 & 0.7 & & 35.4 \\
\hline $\mathrm{Zi}$ & 0.6 & 4.1 & 0.9 & & \\
\hline $\operatorname{Re}$ & 0.7 & 4.8 & 1.0 & & \\
\hline $\mathrm{Se}$ & 0.3 & 2.1 & 0.4 & & \\
\hline We & 0.5 & 3.4 & 0.7 & & \\
\hline $\mathrm{Be}$ & 0.5 & 3.4 & 0.7 & & \\
\hline $\mathrm{Ru}$ & 0.5 & 3.4 & 0.7 & & \\
\hline $\mathrm{La}$ & 0.6 & 4.1 & 0.9 & 17.3 & \\
\hline So & 0.6 & 4.1 & 0.9 & & \\
\hline $\mathrm{Ti}$ & $0.2^{*}$ & 2.4 & 0.5 & & \\
\hline Ho & $0.4^{*}$ & 3.4 & 0.7 & 12.5 & 24.0 \\
\hline At & 0.4 & 2.7 & 0.6 & & 32.9 \\
\hline \multirow{3}{*}{\multicolumn{2}{|c|}{$\begin{array}{l}\text { Average normal. . . . . . . } \\
\text { Highest normal. . . . . . . } \\
\text { Lowest normal. . . . }\end{array}$}} & 3.4 & 0.7 & & \\
\hline & & 4.8 & 1.0 & & \\
\hline & & 2.1 & 0.4 & & \\
\hline
\end{tabular}

* Seven cubic centimeters of serum and a $35 \mathrm{cc}$. aliquot were used instead of the customary $10 \mathrm{cc}$. of serum and a $30 \mathrm{cc}$. aliquot. .

$\mathrm{BaSO}_{4}$ appears to take place but the errors resulting therefrom are not significant. While the amounts weighed are very small and while there are several sources of possible error, the results obtained with the method have been fairly constant. 
TABLE 3

Cardiac and renal disease

\begin{tabular}{|c|c|c|c|c|c|c|}
\hline \multirow[t]{2}{*}{ Name } & \multirow[t]{2}{*}{ Diagnosis } & \multirow{2}{*}{$\begin{array}{c}\text { BaSO4 } \\
m g m .\end{array}$} & \multicolumn{2}{|c|}{$\begin{array}{l}\text { Expressed as } \\
\text { SO } 4 \text { in serum }\end{array}$} & \multirow{2}{*}{$\begin{array}{c}\text { Urea N } \\
\begin{array}{c}\text { migm. } \\
\text { per } 100 \\
c c .\end{array}\end{array}$} & \multirow{2}{*}{$\begin{array}{c}\begin{array}{c}\text { Non- } \\
\text { protein } \\
\text { N }\end{array} \\
\begin{array}{c}\text { mgm. } \\
\text { per } 100 \\
c c .\end{array}\end{array}$} \\
\hline & & & $\begin{array}{c}\underset{\text { per }}{\operatorname{mgm}} .00 \\
\text { cc. }\end{array}$ & $\underset{\text { per }}{m E q}$. & & \\
\hline Gray & Toxemia of pregnancy & 0.8 & 5.5 & 1.1 & & \\
\hline Gray & Toxemia of pregnancy & $0.5^{*}$ & 4.2 & 0.9 & 14.7 & 30.0 \\
\hline Di Leonardo & Mitral disease & 0.9 & 6.2 & 1.3 & & \\
\hline Schuhmacher & Acute nephritis & $1.2^{*}$ & 10.0 & 2.1 & 48.3 & 75.0 \\
\hline $\begin{array}{l}\text { Garntyuk (dupli- } \\
\text { cate) }\end{array}$ & Chronic nephritis & $\begin{array}{l}1.4 \\
1.3\end{array}$ & $\begin{array}{l}9.6 \\
8.8\end{array}$ & $\begin{array}{l}2.0 \\
1.8\end{array}$ & & 68.0 \\
\hline Garntyuk & Chronic nephritis & 1.3 & 8.9 & 1.9 & & 49.2 \\
\hline Gordon & Hypertension & 0.6 & 4.1 & 0.9 & 9.3 & \\
\hline Wilkins & Hypertension & $0.9^{*}$ & 7.5 & 1.6 & 18.7 & 37.8 \\
\hline Snufsky & Uremia & 7.5 & 51.4 & 10.7 & 158.0 & 214.0 \\
\hline Snufsky & Uremia & 5.7 & 39.0 & 8.1 & 138.0 & 200.0 \\
\hline Mason & Hypertension & 0.8 & 5.5 & 1.1 & 9.0 & 22.0 \\
\hline Andrews & Chronic nephritis & 0.9 & 6.2 & 1.3 & 15.4 & 33.8 \\
\hline Putney & Cardiac decompensation & 1.5 & $10.3 t$ & 2.2 & & 38.0 \\
\hline Williamson & Hypertension & 1.0 & 6.9 & 1.4 & & 55.0 \\
\hline Galloway & Hypertension & $0.7^{*}$ & 5.9 & 1.2 & & 40.0 \\
\hline Brown & Hypertension & 0.9 & 6.2 & 1.3 & & 46.1 \\
\hline Geo. Smith & Hypertension & 1.0 & 6.9 & 1.4 & 19.9 & 36.5 \\
\hline Sava & Chronic nephritis & 5.4 & 37.0 & 7.7 & & 160.0 \\
\hline Taylor & Chronic nephritis & 2.1 & 14.4 & 3.0 & & 111.0 \\
\hline
\end{tabular}

* Seven cubic centimeters of serum and a 35 cc. aliquot were used instead of the customary $10 \mathrm{cc}$. of serum and a $30 \mathrm{cc}$. aliquot.

† Following $\mathrm{Mg} \cdot \mathrm{SO}_{4}$ administration.

TABLE 4

Miscellaneous cases

\begin{tabular}{|c|c|c|c|c|c|c|}
\hline \multirow[t]{2}{*}{ Name } & \multirow[t]{2}{*}{ Diagnosis } & \multirow{2}{*}{$\frac{\begin{array}{c}\text { BaSO } \\
\text { weighed }\end{array}}{m g m .}$} & \multicolumn{2}{|c|}{$\begin{array}{l}\text { Expressed as SOA } \\
\text { in serum }\end{array}$} & \multirow{2}{*}{$\frac{\text { Urea } N}{m_{100} \text { cc. }}$} & \multirow{2}{*}{$\frac{\begin{array}{c}\text { Non- } \\
\text { protein N }\end{array}}{\text { mgm. per }_{100} \text { cc. }}$} \\
\hline & & & $\begin{array}{l}\text { mgm. per } \\
100 \text { cc. }\end{array}$ & $m E q . \operatorname{per} L$. & & \\
\hline 1 & Rheumatic fever & 0.4 & 2.7 & 0.6 & & \\
\hline$?$ & C.N.S. lues & 1.0 & 6.8 & 1.4 & & \\
\hline 2 & Acute glaucoma & 0.7 & 4.8 & 1.0 & & \\
\hline 3 & Pneumonia & $0.9^{*}$ & 7.5 & 1.6 & 14.3 & 28.7 \\
\hline 4 & Pernicious anemia & 0.7 & 4.8 & 1.0 & & \\
\hline 5 & Portal cirrhosis & 0.5 & 3.4 & 0.7 & & 41.6 \\
\hline 6 & Diabetes mellitus & 0.8 & 5.5 & 1.1 & & \\
\hline
\end{tabular}

* Seven cubic centimeters of serum and a $35 \mathrm{cc}$. aliquot were used instead of the customary $10 \mathrm{cc}$. of serum and a $30 \mathrm{cc}$. aliquot. 


\section{RESULTS}

From table 1 it may be seen that addition and recovery determinations of sulphate added to serum are quite satisfactory. Table 2 shows that the sulphate content of normal serum is approximately the same as that obtained by Denis. Table 3 shows that the concentration of $\mathrm{SO}_{4}$ in the blood of patients suffering from cardiac and renal disorders is at times markedly increased and that it nearly parallels the retention of nitrogen. Table 4 shows that there is little deviation from the normal $\mathrm{SO}_{4}$ values in certain other pathological conditions.

\section{CONCLUSIONS}

1. The normal $\mathrm{SO}_{4}$ content of serum varies between 0.40 and 1.00 milli-equivalent per liter when determined by the gravimetric method described above and the results are in close agreement with the findings of Denis.

2. In nephritis with nitrogen retention the $\mathrm{SO}_{4}$ ion is retained in the blood and roughly parallels the non-protein nitrogen as Denis has shown. The concentration of $\mathrm{SO}_{4}$ in serum may reach 10 milliequivalents per liter.

3. Inorganic $\mathrm{SO}_{4}$ plays a relatively important rôle in the partition of the acid radicals in the blood in nitrogen retention nephritis.

\section{BIBLIOGRAPHY}

1. Denis, W., Jour. Biol. Chem., 1921, xlix, 311. Sulfates in Blood.

2. White, H. L., Amer. Jour. Phys., 1923, lxv, 537. Studies on Renal Tubule Function. III. Observations on the Excretion of Sulphate, with a Modified Technique for the Determination of Inorganic Sulphate in Blood or Plasma.

3. Kahn, M., and Postmontier, R. S., Jour. Lab. and Clin. Med., 1925, x, 317. Non-Protein Sulphur of Blood. 